\title{
DRVEĆE I ŽIVOTINJE U RELIGIJAMA
}

\section{Ivan Cvitković}

\author{
Akademija nauka i umjetnosti Bosne i Hercegovine \\ Bistrik 7, 71000 Sarajevo, Bosna i Hercegovina \\ e-mail: ivo.cvitkovic@yahoo.com \\ Poštujmo zajedništvo živih bića - ljudi, životinja i biljaka- \\ te borimo se za očuvanje zemlje, zraka, vode i tla.
}

(Kuschel i Küng, 1993)

Sažetak

Ovim radom želimo potaći istraživanja o ulozi drveća i cvijeća u religijama i religijskim tradicijama, te uloge životinja $i$ ptica u religijskim tradicijama. U pripremi rada koristili smo se analizom sadržaja, ponajprije "svetih spisa" (Bhagavad-gite, Biblije, Kur'ana i Talmuda). U uvodu ukazujemo na bavljenje prirodom religija davno prije nastanka ekoloških pokreta. Dovelo je to, u novije vrijeme, i do razvoja zasebne teološke discipline-ekološke teologije. Ni sociologija religije nije mogla izbjeći tematiku odnosa religije-priroda. Prvi dio rada odnosi se na temu koju ćemo rijetko naći u sociologiji religije ili u religiologiji - o drveću i cvijeću u religijama i religijskim tradicijama. Pokušali smo "proći“ kroz povijest religijskih tradicija i naućavanja (od „starih" religija, hinduizma, šintoizma, budizma, taoizma do židovstva, kršćanstva i islama) kako bismo ukazali na značaj drveća i cvijeća u religijskom životu čovjeka (drvo kao totem, uloga planina u religijskim tradicijama, drvo u obrednoj praksi...). Rečeno je i ponešto pojedinačno o drveću koje se najčesćé spominje u mitologijama i religijskim tradicijama (badem, bagrem, hrast, jabuka, lipa, loza, maslina, palma, nar, smokva...). Kakva je uloga cvijeća u religijama i religijskim tradicijama (osobito u obrednoj praksi)? Izdvojili smo ono cvijeće koje najčešće spominju i pismeno analiziraju religijski autoriteti (ciklama, iris, lotos, ljiljan, ruža). Jednako nam je zanimljivo bilo istraživati ulogu životinja i ptica u religijama i religijskim tradicijama. Još smo jednom analizirali kako se na njihovu ulogu gleda iz različitih religijskih perspektiva - od hinduizma, do židovstva, kršćanstva i islama. Osobito nas je zanimala uloga životinja u žrtvenim obredima unutar različitih religijskih tradicija; tradicija proricanja na osnovu dijela tijela neke životinje; izbjegavanje konzumiranja mesa zbog religijske tradicije, itd. Naveli smo i kratak osvrt na to kakvu simboliku pojedine životinje imaju u religijskim tradicijama (bik, deva, jarac, jelen, konj, kornjača, koza, krava, lav, lisica, mačka, magarac, ovca...). I ptice igraju odredenu ulogu u religijskim tradicijama. Zanimalo nas je kakva je simbolika ptica u pojedinim religijskim tradicijama (feniks, golub, grlica, labud, orao, pijetao, roda, sova...). Zaključak je da drveće, cvijeće, životinje i ptice imaju svoju ulogu u religijama i religijskim tradicijama. Osobito njihova uloga dolazi do izražaja u religijskim obredima, najčš́će kao obredno sredstvo.

Ključne riječi: religija, ekologija, sociologija, drveće, cvijeće, životinje, ptice

\section{UVOD}

Povijest religija pokazuje nam da su se one, davno prije nastanka ekoloških pokreta, „bavile prirodom“ i ekološkim katastrofama. Zar starozavjetna priča o Noi nije vid ekološke 
katastrofe? Sve tri abrahamske religije (židovstvo, kršćanstvo i islam) upućuju na balans korištenja prirode i brige za nju. Ne čudi stoga da se počela razvijati i „ekološka teologija" kao zasebna teološka disciplina koja se bavi odnosom religija i okoliša te utjecajem religija na čovjeka i njegov odnos prema prirodi.

I u udžbenicima sociologije religije, kao i u sociološkim esejima o religiji, sve češće nailazimo na interpretiranje odnosa religije - priroda. Sociologe na to upućuju mnoga događanja u religijskim zajednicama poput godišnjih kalendara (koji prate sunčanu ili lunarnu godinu), rituali vezani za pojedina godišnja doba, „sveti dani“ u kojima su zabranjeni težački radovi, i sl. Sve nas to podsjeća na odnos religija prema prirodi, koji se može iskazivati i kroz post ili propise o prehrani (o tome nešto više kasnije), i razne religijske obrede (obredi životnog ciklusa, kalendarski obredi, žrtveni obredi...). U ovom radu ograničit ćemo se na istraživanje uloge drveća i cvijeća u religijama i religijskim tradicijama te uloge životinja i posebno ptica u tim tradicijama.

\section{DRVEĆE I CVIJEĆE U RELIGIJAMA I RELIGIJSKIM TRADICIJAMA}

O drveću i cvijeću u religijama i religijskim tradicijama rijetko ćemo naći pokoji tekst u sociologiji religije ili u religiologiji. Uglavnom se ono, osobito cvijeće, usputno spominje, najčešće među sredstvima obredne djelatnosti. U ovom kratkom tekstu pokušat ćemo "proći“ kroz povijest religijskih tradicija i naučavanja kako bismo ukazali na značaj drveća i cvijeća u religijskom životu čovjeka.

Prvobitna su vjerovanja pokazala da određena stabla mogu biti totemi i kao takva obožavana. U početku, prije nego što su prihvatili monoteizam, i Židovima je totem moglo biti drvo. To obožavanje drveća naziva se dendrologija. Ali, drvo se ne mora obožavati već se prema njemu može imati odnos kao nečem svetom, različitom od običnog drveta. Naravno, razlika nije u fizičkom, već simboličkom značenju. Za neko drvo, sljedbenici određenog religijskog pravca, smatraju da se ono razlikuje od običnog, profanog drveta - da je ono sveto. Najčešće su među sveto drveće ubrajani lovor, hrast, smokva, palma, maslina. Spomenimo da je i jasen bio skandinavsko sveto drvo kao i sakaki u japanskom šintoizmu. Šintoisti ga sade oko hrama i njegove grančice upotrebljavaju u obredima pročišćenja. Dakle, drvo može biti „sveto“ (kao što su bili lipa i hrast kod Slavena), kao i planinski vrh. Inače, obožavanje drva života, drva spoznaje, lipe kod Slavena i slično naziva se i filolatrija. Sveto može biti drvo u cjelini, njegov cvijet, grana (maslinova ili palmina grančica). Svakako treba imati u vidu da nije riječ o obožavanju drva po sebi, jer ih ništa fizički ne razlikuje od ostalog drveća, već o obožavanju simbolike koju ono izražava.

Ne samo drvo, već i planine igraju važnu ulogu u religijskim tradicijama širom svijeta. Za planine se kod mnogih naroda vjerovalo da su domovine bogova. Tako se i za Olimp vjerovalo da je mjesto boravišta bogova. Bogovi oluja povezani su sa planinama. „Tvoj dah puše nad planinama", kaže se u hvalospjevu egipatskom bogu Ptah. Planine su svete, ali su ponekad i sami bogovi. Među najpoznatije svete planine spadaju Olimp, Himalaji, Kavkaz, Koja (na koju hodočaste japanski budisti), Fudži (na koju hodočaste 
šintoisti), Zmajeva vrata (kamo hodočaste kineski taoisti), Ulupu (sveta planina Aboridžina ${ }^{1}$ u Australiji). Kailsa je sveta planina hinduista (koji vjeruju da je ona dom boga Šive) i tibetanskih lamaista. Atos je sveta gora u Grčkoj, centar monaškog života na istoimenom otoku. To su sveta mjesta ukazanja, objava, boravišta bogova; planine na kojima se odvijao neki važan događaj za religijsku zajednicu, poput najave ili davanja Objave, itd. I Mojsije je primio Deset Božjih zapovijedi na gori Sinaju. Zato ih nazivaju svetim planinama. Tamo se često podižu i hramovi u koje se hodočasti. Tako su i taoisti u Kini razvili hodočašća u sveta planinska mjesta, a najpoznatije hodočašće je u Šantungu. Od živućih religija, možda drveće i planine najvažniju ulogu igraju u šintoizmu (Japan). Šintoisti vjeruju da kamiji (njihovi bogovi) mogu boraviti u svetim planinama, u drveću. Hramove grade od drveća. Tradicija je da se iznova grade svakih dvadeset godina. Među istaknute obrede koje vodi šintoistički svećenik ubraja se harai, ritual pročišćenja mladicama svetog drveta (sakai).

Drveće i šume, osobito u nekim vjerovanjima i mitologijama, imaju i svoje bogove. Tako je Pan u grčkoj mitologiji bio bog šume, pastira i zaštitnik stada. U rimskoj je mitologiji to bio bog Faun. Pomona je bila starorimska božica rodnosti drveća. Hazzi je planinski bog u vjerovanjima Hetita. Dijana je bila rimska i ilirska božica zaštitnica šuma. Drijade su bile nimfe drveća u vjerovanjima starih Grka. Prema vjerovanjima Južnih Slavena, bukumire, nadnaravna bića, živjela su po šumama. I Romi vjeruju da njihova Božja Majka, zaštitnica djece, boravi u planinama. Hinduisti slave drveće, ono će donijeti cvjetove i plodove. Potiču sadnju drveća, čuvanje šuma, osuđuju njihovo uništavanje. Smatraju da su stabla drveća poput djece. Vjeruju da oni koji sade drveće nikada neće otići u pakao. Pošto su vjerovali da bogovi žive u planinama, hinduisti su tamo pravili svoje hramove u stilu planinskih kuća. I ne samo to: hinduistički brahmani odlaze u šumsku osamu izučavati hinduističke svete spise. Džaini ${ }^{2}$ ne smiju obavljati nijedan posao za obradu drva, jer se tijekom te obrade nanosi bol drvu. Sljedbenici Ainu religije ${ }^{3}$, u Japanu, vjeruju da duše borave u drveću. Također, i sljedbenici vudu pokreta ${ }^{4}$ vjeruju da u planinama leži duh $s$ kojim mogu ostvariti komunikaciju. Vjeruju da se loše (ljude?) smješta u drveće.

Planine su izvor rijeka pa su postale i simbolom rodnosti. U Starom zavjetu čitamo: „Evo dolaze dani [...] kada će planine procuriti mladim vinom“ (Amos, 9:13). Za neko se drveće vjeruje da njihovi plodovi, lišće ili kora čine svetu hranu. Drvo je simbol ži-

\footnotetext{
1 Malobrojno domicilno, urođeničko stanovništvo u Australiji. Najvažniji sakralni predmet im je tjuringa (plosnati predmet od kamena ili drveta) koji drže u najvećoj tajnosti. Zalažu se za suživot s prirodom i njeno očuvanje.

2 Pripadnici džainizma, jedne od triju religija nastalih u indijskoj civilizaciji. Riječ je o isposničkoj religiji nastaloj u šestom stoljeću. Propovijedaju nenasilje prema svakom živom biću pa i prema drvetu.

3 Religija domorodačkog stanovništva u Japanu. Najviše štuju božicu Kama Fuči, zaštitnicu ognjišta. U njezinu čast nikad nisu gasili vatru na ognjištu.

4 Sinkretički religijski pokret osnovan na Haitiju i Dominikanskoj Republici. Rasprostranjeni su i u Nigeriji, Beninu, Gani, Togou. Zasniva se na katoličkim ritualima i zapadnoafričkim religijskim tradicijama koje su sa sobom donijeli robovi iz zapadne Afrike. Naziv dolazi od riječi „vudu“, što bi značilo „duh“. Pored svećenika i žene mogu biti svećenice.
} 
vota, besmrtnosti. Zato se u mnogim religijskim tradicijama govori o drvu života (lat. arbor vitae), u mitologijama mnogih naroda, simbolu životne borbe. Za Slavene drvo života označavalo je život, izvor svega što postoji. Prema slavenskoj mitologiji, kad čovjek umre njegova duša odlazi u stablo i tamo ostaje zauvijek. Drvo života simbol je besmrtnosti i dara razlikovanja vječnog od prolaznog. Smatraju ga nacionalnim drvom u Gruziji, Bahrainu. Za razliku od drva života postoji i drvo spoznaje, kao što je smokva u budizmu. U knjizi Postanka (Stari zavjet), jabuka je drvo spoznaje dobra i zla koje je zasadio Bog u Raju. Zašto je Bog želio čovjeku uskratiti spoznaju? Zašto mu je zabranio jesti jabuku s drva spoznaje? Odgovor teologa glasi - da bi se čovjek vježbao u vrlini vjernosti prema svome Stvoritelju. U sedmoj suri govori se o plodu sa zabranjenog drva, ali se ne kaže koje je to drvo (7:18-21). I u suri 20:115 piše o „zabranjenom stablu, o stablu vječnosti“ (20:120).

Drvo ima određenu ulogu i u obredima. U nekim se religijskim tradicijama tijelo umrlog ostavljalo na drveću lešinarima, a kasnije bi pokopali kosti. Tako su sljedbenici zoroastrizma, izlagali posmrtne ostatke lešinarima. Parsi, sljedbenici mazdaizma, koji su pred naletom islama u osmom stoljeću emigrirali u Indiju, umrlog su izlagali kao hranu pticama lešinarima. To su isto radili i Tibetanci. Čini se da su ovaj postupak s mrtvim tijelom prakticirali i pripadnici sljedbe pavlina (8. stoljeće). Drvo je materijal za izradu lijesa i tabuta. Ikone (Bogorodičine ili svetačke slike) u pravoslavlju najčešće se rade na drvu. U nekim se kulturama, poput azijskih, hramovi grade od drva, ali ne samo u Aziji. Crkve brvnare nekad su građene po Srbiji, osobito u vrijeme Otomanskog imperija (mogle su se lako prenositi s jednog mjesta na drugo). Ta se tradicija zadržala do danas. Tako se crkve brvnare mogu i danas naći po Srbiji, osobito u planinskim područjima (npr. na Mokroj gori). Tu je i tabulat, drveni crkveni strop na kojem su izvedene slike. U nekim religijskim tradicijama izgrađuju se sveti obredni predmeti od posebnog drva. Često su to hrast, datula, vrba. Inače, vrba je u nekim religijskim tradicijama simbol žalosti, a njezino cvjetanje najavljuje dolazak proljeća. Stari Slaveni smatrali su je svetim drvom koje simbolizira postojanost životnih ciklusa. Inače, vrba je simbol čistoće i besmrtnosti, ljepote, ali u isto vrijeme povezana je $s$ tugom te je epitet „žalosna vrba“ dobila zbog visećih grana. U Poljskoj je smatraju nacionalnim drvom. Grane se palme, ili masline, na Cvjetnicu (nedjelja prije Uskrsa) nose u hramove. Maslinove grančice koje katolici na Cvjetnicu nose na blagoslov u crkvu, simboliziraju pobjedu nad grijehom. U kršćanskoj se tradiciji i maslinovo ulje koristi u obredu. U nekim kulturama vjeruje se da stablo mimoze štiti od zlih uroka, bolesti, pa ga se sadilo uz kućna dvorišta.

Stari je običaj među kršćanima da se na Badnji dan (dan prije Božića) ujutro siječe Badnjak: grana hrasta, cera ili lijeska, i prislanja uz kuću. Zanimljiva je predaja među Litvancima o kojoj piše Graus: „Karaimima strah, strahopoštovanje prema smrti, zapovijeda da na groblju izbjegavaju skoro sve što se inače čini i obavlja na grobljima. Drveće, na primjer! Ovi moćni hrastovi, što tu rastu, i drugi hrastovi koji bijahu slomljeni pa su se srušili na livadu ili ih je zadržalo granje susjednih stabala, ti trupci koji trunu u travi, a koji su prije pedeset, prije stotinu godina stršili u visinu - sve se to nije smjelo dirati, uklanjati, nije ih se smjelo podrezivati, a pogotovo ne obarati“" (Graus, 2018:208). Drvo 
se koristilo i u drugim situacijama. Tako je, prema evanđeljima, i Isus razapet na drveni križ. „Vaga je u karainskoj kući smjela stajati samo u ženskoj sobi i smjela se izrađivati samo s drvenim čavlima; metalni čavli bili su rezervirani za lijes: drvom se čovjeka dočeka, metalom se oprašta od njega, drvo je živo, a metal stavlja pečat na ono što je bilo živo i sad je mrtvo i treba zauvijek ostati među mrtvim" (Graus, 2018:204). Tuba je drvo pod kojim će, na sudnjem danu, po vjerovanjima pripadnika islama, vjernici naći zaklon od vrućine. $U$ islamskom pisanom religijskom autoritetu, Kur’anu, na više se mjesta govori o drvu. Tako u suri 55:6 stoji da se drveće podvrgava Božjoj odredbi, a u suri 5:48 govori se o dva dženeta sa stablima. Stari nas zavjet upoznaje s Mojsijem kako baca neko drvo koje mu pokaza Jahve i gorka voda postade slatka (Izlazak, 15:25). U Postanku 2:9 govori se o stablu „spoznaje dobra i zla“ u Edenu. U Novom zavjetu piše kako se svako stablo koje ne donosi roda siječe i u oganj baca (Lk, 3:9).

Evo ponešto o drveću koje se najčešće spominje u mitologiji i religijskim tradicijama. Akacija je maleno istočno-afričko drvo čije ime znači nevinost. Kod masona simbolizira čednost i nevinost. Badem, simbol budnosti, kad on procvate, najava je to proljeća. Bademi su sazreli i na Aronovom štapu (Br, 17:23), stoji u Starom zavjetu. Bagrem se najčešće spominje u židovskoj religiji. Jahvi se prinose darovi od bagremovog drva (Izlazak, 25:5). I kovčeg se pravi od bagremovog drva (Izlazak, 25:10). I stol na kojem će se Jahvi prinijeti darovi treba biti napravljen od bagremova drva (Izlazak, 25:23). Glog je drvo za koje su Južni Slaveni vjerovali da ima snagu suprotstavljanja zlim duhovima. Prema narodnom vjerovanju, glogov kolac tjera vampire i vještice, zle duhove, bolesti. U narodu postoji uzrečica: „Bez glogovog koca ništa mu biti ne može“. Hrast je drvo štovano u mnogim pučkim vjerovanjima, a štovali su ga Kelti i Slaveni. U staroindijskim religijama vrijedio je kao drvo boga gromovnika, a kod starih Germana Donar je bio bog hrasta čiji je dan bio četvrtak. U rimskoj mitologiji tu ulogu ima Jupiter dok je Perun bio zaštitnik hrasta. U Starom zavjetu (Pos, 35:8) čitamo da je Rebekina dojilja Debora sahranjena pod hrastom, koji se otad zove „Tužni hrast“. Smatraju ga nacionalnim drvom u Bugarskoj, Estoniji, Italiji, Latviji, Litvi, Moldaviji, Njemačkoj, Rumunjskoj, SAD, Srbiji. Katolici i pravoslavni kršćani od hrastova drva sijeku badnjak. Može to biti i mlado cerovo ili javorovo drvo ${ }^{5}$ debljine ruke ili noge. Onaj među pravoslavcima koji siječe badnjak okrene se istoku, tri puta prekrsti i izgovara molitvu „Pomoz Bože i Badnjače sveti“, i u tri maha, sjekirom odsiječe granu pazeći da padne na istočnu stranu. Badnjak se prisloni uz kuću s istočne strane, uz snop slame. U urbanim se sredinama uoči Badnjaka prodaju hrastove ili cerove grančice. Jabuka je simbol zla, ali je ujedno i bila drvo spoznaje dobra i zla s kojeg je Adamu i Evi bilo zabranjeno uzimati plodove. ${ }^{6}$ U nordijskoj mitologiji božica Iduna je čuvarica zlatne jabuke koja daje vječnu mladost, a u grčkoj mitologiji, postojale su hesperide, nimfe koje su u vrtu bogova čuvale zlatnu

5 U Kanadi javor smatraju nacionalnim drvetom.

6 „Zar nas Bog ne izlaže iskušenju u raju, gde upozorava Adama i Evu da ne jedu jabuku sa drveta znanja zašto je uopšte stavio ovo drvo, pa onda čak i skrenuo pažnju na njega?““ (Žižek, 2019:291) 
jabuku života. Prema grčkoj mitologiji mladić Paris dodijelio je jabuku najljepšoj ženi Afroditi. Nekad se i u Bosni i Hercegovini djevojkama i ženama darivala jabuka za religijske blagdane. Mladenka je, nakon dolaska svadbene povorke pred kuću mladoženje, trebala prebaciti jabuku napunjenu metalnim novcima preko krova kuće kako bi imala sretan brak.

Jela je simbol ljudi koji se odlikuju krepošću i strpljivošću. Jela ukrašena nakitom postavlja se za božićne blagdane u crkvama i domovima, a njezine zelene grane simboliziraju početak, novu godinu. Lipa, simbol prijateljstva, uz hrast važi kao znak nježnosti. Postojalo je vjerovanje da lipa čuva čovjeka od zla i uroka. Slaveni su štovali lipu kao što su Germani štovali hrast dok ju nacionalnim drvom smatraju u Češkoj, Latviji i Sloveniji. Drvo lovor se smatralo svetim drvom u starorimskim i starogrčkim vjerovanjima, a prema grčkoj mitologiji, Apolon je volio i progonio nimfu Dafne te ju je Gea pretvorila u lovoriku, otud i naziv daftomantija za proricanje na osnovu gorenja lovorove grane. U Delfima je lovorovo stablo bilo glasnik boga Apolona te ga u Grčkoj smatraju nacionalnim drvetom. Rimski su carevi oko glave nosili lovorov vijenac od zlatnih listića, a u drevnoj Ateni lovorov vijenac zamijenjen je vijencem od maslinovih grančica, jer je maslina bila simbol grada. Lovorov vijenac čest je motiv u arhitekturi, dizajnu odjeće i slično dok se u Indiji lovor žrtvovao u kultu boga Šive?.

$\mathrm{U}$ različitim religijskim tradicijama i mitovima spominju se loza $i$ vinograd. Tako je Ampel, u grčkoj mitologiji Dionizijev ljubimac kojeg je pretvorio u lozu, Agura bog je zaštitnik vinograda u vjerovanjima Gruzijaca dok je Bolon Dz’acab bio majanski bog loze i podrijetla. Grožđe se spominje u Suri 2:266, a u suri 36:34 stoji da je Bog stvorio vinograde te u suri 13:4 spominje se vinograd. U suri 16:67 stoji: „Od plodova palmi i grožđa vi uzimate opojno piće i lijepu hranu", a u suri 23:19 ponavlja se kako je Bog stvorio „vrtove hurmi i grožđa, u njima imate mnogo voća i od njega jedete“. U suri 78:32 ističe se da će u dženetu biti „vrtova i grožđa“. Sura 80:28 potvrđuje da je Bog ljudima dao grožđe. Stablo lijeske, drvo za čiju šibu se kod Srba vjerovalo da ima magičnu snagu te da u nju ne udara gro, važila je i kao drvo znanja. Maslina je simbol mira, rodnosti, očišćenja, snage, pobjede, nagrade te je smatraju nacionalnim drvećem u Albaniji, Eritreji, Italiji, Izraelu, Portugalu. Grci su smatrali da je maslina posvećena božici Ateni, u Rimu Jupiteru i Minervi, a od grana masline u Zeusovu gaju na Peloponezu pleli su se vijenci za pobjednika u olimpijskim igrama. I danas, kad kreće olimpijski plamen iz Grčke, vidimo djevojke obučene u bijele haljine s vijencem ispletenim od maslinovih grančica na glavi i bakljom olimpijskog plamena u ruci. Kinezi su maslini pripisivali zaštitnu vrijednost, u Japanu je bila simbol pobjede, u židovskoj i kršćanskoj religiji to je simbol mira dok se u islamu se o njoj govori kao o stablu blaženih. U suri 23:20 piše da je Bog stvorio maslinu koja daje ulje. U suri 24:35 ističe se kako je stablo masline bla-

7 Šiva, jedan od glavnih bogova hinduizma koji čini trojstvo s Brahmom i Višnom. Kult mu se razvio u južnoj Indiji i Kašmiru. Njegovi štovatelji stavljaju na čelo tri vodoravne crte. Simbol mu je uzdignuti falus. 
goslovljeno. U suri 80:29 kaže se da je Bog ljudima dao masline i palme, a vodu je Bog stvorio da čovjek uzgaja masline, palme, grožđe (16:11), dok u suri 95:1 se spominje maslina. U kršćanstvu je maslina poznata po tome jer je Isus sjedio na Maslinskoj gori (Mt, 24:31) odakle je na magarcu krenuo u Jeruzalem (Lk, 19:29-35). Nar / sipak voćka je čije plodove treba jesti, a u budističkoj tradiciji, nar je jedna od triju blagoslovljenih voćki, u kršćanstvu je simbol Crkve dok kod Kineza simbolizira rodnost i sretnu budućnost. Kod masona zatvoren plod simbolizira skromnost masona, a otvoren njihovu sklonost da ostvare zajedničko dobro. Pripadnici židovske religije za blagdan Roš hašana (Nova godina), uz večeru, uzimaju nekoliko zrna nara da bi život u novoj godini bio ispunjen kao nar zrnima. Vjeruju da nar ima 613 zrna, koliko i zapovijedi u Tori. Židovi na rub ogrtača (dio obredne odjeće) vezu šipak od „ljubičastog, crvenog i tamnocrvenog prediva“ (Izlazak, 28:33). I u islamskom svetom spisu, Kur’anu, spominje se šipak. Prema suri 55:68 u dženetu će biti „,voća, hurmi i šipaka“. Nadalje, narančino se stablo smatra simbolom čistoće, čednosti i velikodušnosti. Palma je kod Rimljana bila simbol pobjede, a palminu grančicu, uz maslinu, nose katolici na cvjetnu nedjelju u crkvu na blagoslov dok su sljedbenici religije umbanda ${ }^{8}$ razvili proricanje iz palmina oraha.

U suri 6:99 spominje se palma, grožđe i šipci, a u 6:141 spominju se masline. Smatraju je nacionalnim drvetom u Beninu, Liberiji, Maršalovim otocima, Mauritaniji, Obali Slonovače, Sudanu. Platana je simbol dobrotvornosti i Kristove čovjekoljubivosti, a smokva je u budizmu i džainizmu simbol savršenstva, kontemplacije, meditacije i spoznaje. Sidarta Gautama, uz čije se ime vezuje nastanak budizma, sjedeći pod smokvom, kasnije nazvanom drvo bodhi (drvo buđenja) sjedio 24 sata i „otkrio“ tajnu prosvjetljenja. I hinduisti obožavaju smokvino drvo. Prema Bhagavad-giti, smokva je sveto drvo. U Indiji „ga često obožavaju kao jedno od svojih dnevnih jutarnjih obreda“ (Bhagavad-gita, 1982:466). Smokva je drvo spoznaje. „Tada se obadvoma [Adamu i Evi] otvore oči i upoznaju da su goli. Spletu smokvino lišće i naprave sebi pregače", čitamo u Starom zavjetu (Post, 3:7). Postala je simbolom požude, ali i plodnosti (zbog mnogobrojnih sjemenki u njenom plodu). Isus je prokleo smokvu na kojoj nije bilo plodova i ona je usahla (Mk, 11:14). Ponavlja to i Matej: Isus je usahnuo neplodnu smokvu (Mt, 21:19), kad smokvino lišće propupa, blizu je ljeto (Mt, 24:32). „Isus je prokleo smokvu [...] dvadeset vekova kasnije, ne znamo da li su plodovi koje je davalo nesrećno drvo bili beli ili tamni, rani ili pozni, sorte zamorčica ili petrovača", piše Jose Saramago u romanu „Kameni splav“ (2017:46). U suri 95:1 spominju se smokve te se na osnovu smokvina lista može vršiti proricanje (sikomantija), a u Turskoj je smatraju nacionalnim drvetom. Prema kršćanskoj mitologiji, u vrijeme Kristove smrti na križu sva stabla su se sagnula od boli, osim topole te je zbog toga njezino lišće osuđeno na vječno treperenje.

O voću se od svetih spisa monoteističkih religija najviše piše u Kur’anu. U dženetu „ćete imati mnogo voća od koga ćete jesti“ (43:73). U suri 55:52 kazuje se da u dženetu ima-

8 Sinkretistička religija dijela crnaca u Brazilu nastala 1920. u okolini Rio de Janeira. Zasniva se na prvobitnim vjerovanjima crnaca sa zapadnih obala Afrike (najviše iz naroda Joruba) i katoličkim običajima i obredima. Nazivaju je i „santerija“. 
ju „dvije vrste voća“ Prema suri 56:20 u dženetu će imati „raznovrsnog voća od koga će moći birati“. Tu ima i banana načičkanih plodovima (56:29) i mnogobrojnog voća (56:32) koje nikad ne prestaje niti je zabranjeno (56:33).

Kada govorimo o cvijeću, u starogrčkim vjerovanjima postojao je obred antesterije, trodnevne svečanosti cvijeća koja se, u čast boga Dioniza, održavala svake godine u Ateni. U mnogim religijama svijeta, cvijeće je puno simbolike i služi u obredima, osobito pri obredima rođenja, sklapanja braka i smrti. Osobito se koristi u hinduističkim budističkim, taoističkim obredima, kao obredno sredstvo, a cvijeće u tim religijama označava prolaznost tijela te najveću simboliku ima lotos. Također, pripadnici ovih triju religija svojim božanstvima, kao žrtveni dar, prinose cvijeće. U raznim religijskim kulturama prakticira se posjeta grobovima umrlih predaka. Uobičajeno se na grobove nosi paran broj cvjetova u buketu zbog nekadašnjeg vjerovanja da ih pola pripada duši, a ravnomjerna druga polovina tijelu umrlog. Na Dušni dan (Dan mrtvih) ${ }^{9}$ katolici nose cvijeće na grobove umrlih predaka te je uobičajeno da se na Cvjetnu nedjelju umivaju vodom u koju su prethodne večeri potopljene latice raznog mirišljavog cvijeća. Židovi za blagdan Šavout (Pedesetnica) sinagoge ukrašavaju zelenilom i cvijećem u čast dolaska ljeta i životne radosti dok je kod pravoslavnih Srba bio je običaj da se djeci u kovčeg, pri sahrani, stavlja cvijeće. Imena se daju djeci po precima, imenu neke filmske zvijezde, pjevača, omiljenog lika iz neke knjige, od sastava imena oca i majke te nas neka imena podsjećaju na cvijeće: Iris, Florijan, Flora itd.

Cvijeće koje se najčešće spominje u religijama i religijskim tradicijama je ciklama, cvijet posvećen Djevici Mariji čija crvena boja u sredini cvijeta simbolizira krvarenje Marijina srca od žalosti (Badurina, 1979). Iris / perunika je žena boga Peruna u starorimskoj mitologiji čije se ime zadržalo kod Slavena do danas u biljci perunici. To je također i cvijet Djevice Marije, kršćanski simbol. Jedan od najčešćih simbola indijske ikonografije je lotos na kojem sjedi Buda ukazuje na njegovo božansko podrijetlo te je najčešći položaj tijela tijekom meditacije u obliku lotosa. U budističkoj se tradiciji Buda prikazuje kao plamen koji izlazi iz lotosa, lotos je jedno od osam blaga ili povoljnih znakova u kineskom budizmu. Prema hinduističkoj tradiciji, Buda i Agni ${ }^{10}$ rođeni su iz lotosa. $\mathrm{Na}$ pragu hrama lotos označava boravište božanske prirode. U taoizmu lotos predstavlja svjetlost, tao transcendentalnu moć i duhovni preporod. "Om mani padme hum “, odnosno, „gle dragulj u lotosu“, mistična je molitvena formula u budizmu i lamaizmu, raširena u Tibetu i Nepalu. Značila bi „Neka žive tri sveta dragulja u lotosu“, a nju vjernici izgovaraju i pišu na zidovima hrama te se u lamaizmu ova mantra ispisuje i na barjak. Simbol Sai pokreta ${ }^{11}$ (Sarva dharma) predstavlja latice lotosa unutar kojih se na-

9 Spomen na duše umrlih obilježava se drugog studenog, dan nakon blagdana Svih svetih. Šintoisti dan mrtvih obilježavaju od trinaestog do šesnaestog srpnja (oko 90\% Japanaca godišnje obilazi grobove svojih predaka). $10 \mathrm{U}$ hinduizmu, bog vatre i žrtvovanja, štovan i kao zaštitnik domaćeg ognjišta.

11 Hinduistička sljedba nastala tridesetih godina XX. stoljeća. Imaju svoje sjedište i u Sarajevu, Mostaru, Zenici, Tuzli, Banja Luci, Zavidovićima. Vjeruju u jednog boga kojeg pripadnici različitih religija nazivaju različitim imenima. Zagovaraju pacifizam, nenasilje, toleranciju. Vjeruju da je osnivač, Sai Baba, budući izbavitelj. 
laze simboli najpoznatijih živućih religija (kršćanstva, islama, židovske religije, budizma, mazdaizma), a na vrhu je slog „OM“. Ljiljanov cvijet simbolizira bjelinu, čistoću, djevičanstvo, simbol procvata. Nalazimo ga na mnogim slikama koje predstavljaju detalje iz vjerskog života npr. na slikama u crkvama čest motiv je kako anđeo Gabrijel dolazi Mariji s grančicom ljiljana. Ljiljan je simbol i Kristovog uskrsnuća te ga nalazimo u kršćanskoj tradiciji kao „prateći amblem“ uz slike Djevice Marije i svetog Ante. Ruža je simbol pobjede, ponosa kao i cvijet Venere, božice ljubavi. U starom Rimu postojao je blagdan ruža (Rozalija) te su na taj dan ruže darivane i nošene na grobove umrlih. Ruža se nalazi u sredini križa (tzv. ružokriž) simbola mistične zajednice Rozenkrajcera. Inače, ruža je simbol tajnih društava te simbol ženske spolnosti. U kultovima koji su štovali božice, ruža s pet latica predstavljala je pet postaja života žene - rođenje, mjesečnicu, majčinstvo, menopauzu i smrt. Na sahrani slobodnog zidara u grob mu stavljaju ruže, a u kršćanskoj simbolici, crvena je ruža znak mučeništva, a bijela znak moralne čistoće. Uobičajilo se u našoj regiji da bliža rodbina stavi ružu u grob pokojnika (bijelu ako je riječ o djetetu, mladiću ili djevojci, crvenu ako je riječ o odrasloj osobi).

\section{3. ŽIVOTINJE I PTICE U RELIGIJAMA I RELIGIJSKIM TRADICIJAMA}

Životinje su imale, kroz povijest, svoje mjesto u religijskim vjerovanjima, praksi, obredima, religijskoj umjetnosti, književnosti, plesu inspiriranim religijama, i sl. Tako se i desilo da su religijske tradicije imale utjecaja na čovjekov odnos prema raznim životinjama, sve do njihovog obožavanja. Vremenom se razvila zoolatrija, štovanje „svetih“ životinja ili božanstava u životinjskom obliku, kult životinja. Uobičajeno se u povijesti religija smatra kako je animalizam vjerovanje da se neki ljudi mogu preobraziti u životinje kako bi drugima nanosili zlo. Među mnogim božanstvima nalazimo i ona koja se odnose na životinje. Tako je Hinkon bog lova i gospodar životinja u vjerovanjima naroda Tunga iz Sibira, stari su Egipćani vjerovali da je božanstvo Ra stvorilo životinje i biljke, Cernunnos je bio keltski bog zaštitnik životinjskog carstva, itd.

Na mnogim slikama božice su naslikane sa životinjama i pticama, poput Afrodite na guski ili sa golubovima, Atene sa sovom, Artemide s jelenom, u kršćanstvu Eve sa zmijom, Marije sa golubicom, itd. Religijske tradicije svoj stav o pojedinim životinjama prenose $s$ generacije na generaciju, bilo da se radi o prinošenju neke životinje u obredima, bilo da se radi o zabrani konzumiranja njezinog mesa i sl. Postoje i religijske tradicije koje zabranjuju okrutnost prema životinjama. Prema hinduističkom ciklusu postoji karma, vjerovanje kako čovjek može u drugom životu postati životinja te prema hinduističkoj karmi, duše grešnika odlaze u tijela životinja i biljaka. Sljedbenici džainizma vjeruju da se duša nastanjuje i u životinjama te su zbog ahimse (nenasilja) odbacili brahmansku praksu prinošenja životinja na žrtvu. Nije im čak dozvoljeno ni bavljenje lovom, jer je to nasilje nad životinjom. O odnosu prema kravi u hinduizmu bit će riječi nešto kasnije. Za pojedine religije, poput židovske, neke su životinje - poput divljih - tabui. U Starom zavjetu čitamo kako Bog židovima saopćava: „Neka vas se boje i od vas strahuju sve ži- 
votinje na zemlji, sve ptice u zraku, sve što se po zemlji kreće, i sve ribe u moru" (Post, 9:2). U živućim religijama, osim indijskih, kao da se malo pažnje poklanja životinjama i njihovoj patnji. Ne proizlazi li to iz njihovog stava da životinje nemaju dušu (pa su neosjetljive). Prema Bibliji, Bog nalaže Adamu da nadjene životinjama imena. U Knjizi Postanka 2:19 kaže se da je Bog od zemlje stvorio sve životinje: „Tada Jahve, Bog, načini od zemlje sve životinje u polju i ptice u zraku, i predade ih čovjeku da vidi kako će koju nazvati, pa kako koje stvorenje čovjek prozove, da mu tako bude ime“. U Knjizi Postanka 7:2 Jahve kaže Noi: „Uzmi sa sobom od svih čistih životinja po sedam parova: mužjaka i njegovu ženku“. U više sura Kur’ana čitamo o životinjama: „Koliko ima životinja čije izdržavanje ti ne snosiš (29:60); Bog je na zemlji „razmnožio svakovrsne životinje“ (31:10). U suri 36:71 piše da je Bog stvorio čovjeku životinje, a u suri 39:6 kaže se da je stvorio „osam pari životinja“. U suri 40:79 kaže se da je Bog ljudima „stvorio životinje da [neke] od njih jašete, a od [nekih] jedete“. U suri 43:12 kaže se da je Bog stvorio „životinje koje ćete jahati“. I u suri 45:4 stoji da je Bog stvorio životinje koje postoje na zemlji: „Allah je stvorio svaku životinju od vode: neke od njih gmižu na svom trbuhu, neke idu na dvije noge, a neke na četiri“ (24:45). Sura 16:115 upozorava: „Allah vam je zabranio samo lešinu, krv, svinjsko meso i [meso životinje] koja je zaklana u ime drugog osim u Božje“. U suri 2:28 piše o klanju životinja za kurban: „Pa jedite od njih [meso] i nahranite [tim mesom] nevoljnika siromaha“. I u suri 22:34 piše o klanju kurbana, ausuri 16:5 „I životinje je stvorio. Vi imate od njih [odijela] za zagrijavanje, [razne] kosti i od njih [životinja] vi jedite“. „I vi u njima imate ljepotu kada ih vraćate s paše i kada ih izvodite na pašu“ (16:6). U suri 16:66 piše: „Zaista vi imate pouke u životinjama. Mi vas napajamo iz hrane u utrobama njihovim [...] mlijekom čistim i pitkim onima koji ga piju“, dok u suri 16:80: „Dao vam je [Bog] od životinjskih koža kuće [čadore] [...] a od njihove vune, dlake i kostrijeti [koristite se] prostirkom...". U suri 6:142 govori se o domaćim životinjama za nošenje tereta ne imenujući ih ponaosob. U suri 6:143 kaže se da je Bog stvorio ovcu i ovna; kozu i jarca; od deva i goveda dvoje (6:144). U suri 6:146 kaže se da je Bog židovima zabranio životinje koje imaju kopita, salo od goveda i brava. U suri 5:2 daju se upute vjernicima kako su im dozvoljene životinje osim onih zabranjenih (svinjetina, meso uginulih životinja, od zaklanih životinja „u ime drugoga, a ne u ime Božje“; što je probodeno; što je naklala divljač (5:4). Dopušteno je konzumirati meso od ulova kojeg su ostvarile za lov obučene životinje (5:5). Neki narodi su za svoje grbove birali životinje (orla, vuka, lava, medvjeda...).

Franjo Asiški (1182-1226), osnivač franjevačkog reda, sve je Božje tvorevine nazivao braćom i sestrama. Zemlja je tako naša Majka i naša sestra. U poemi „Pjesma stvorova“, Sunce naziva „bratom“, Mjesec također „bratom“, Zvijezde „sestrama“, vjetar je „brat“, voda je „sestra“, oganj je „brat“. Izražavao je zabrinutost za životinje te u životinji nije vidio životinju nego stvora Božjeg. Životinje se često prinosi kao žrtvu u religijama. Riječ je o tzv. krvnoj žrtvi. Naravno, žrtveni dar može biti i biljni ili tekući. Za žrtveni dar možemo reći da je to komunikacijski znak u odnosu čovjek-Bog. Učenje po kojem se Bog može umilostiviti prinošenjem krvnih žrtava naziva se hematoteologija. Nekad su se za žrtvu prinosili ljudi, najčěšce mladići ili djevojke, ali je ta praksa uzmicala pred 
prinošenjem životinja, žitarica i cvijeća. Životinje su žrtvovane i žrtvuju ih za oprost grijeha: „Krivnja je klala nevinost“, kako je zapisao rimsko-njemački car Fridrich II. u XIII. stoljeću (Stern, 1993:206). Najčešće se kao krvne žrtve prinose kokoš, janje, ovca, deva, krava, koza, govedo, svinja, konj, pas. U religijama zapadne Afrike najčešće su to patka i kokoš, ali mogu biti i koze i ovce. Osnivač budizma Gautama, odbacio je praksu ubijanja životinja radi žrtvovanja, međutim, pripadnici nekih plemena u indijskoj središnjoj državi Madhya Pradesh nude dijelove tijela tigrova svojim božanstvima, vjerujući da će to odstraniti zlo i donijeti im sreću. Hinduisti su prije tisuću godina kao žrtvu prinosili konja dok se u vedskoj tradiciji, ubijanje životinja u žrtvenoj vatri ne smatra činom nasilja i narušavanja ahimse (nenasilje). Šintoisti u Japanu prvog siječnja ne smiju ništa raditi te na taj dan, prije izlaska sunca, u svetištima kao žrtveni dar prinose ribu, vodu, povrće, voće. Kineska godina povezana je s astrologijom i svaka dobiva ime po jednoj od dvanaest životinja kineskog zodijaka: štakor, bik, tigar, zec, zmaj, zmija, konj, koza, majmun, pijetao, pas, svinja. Prema predaji, Buda je pozvao životinje i redoslijedom kojim su one dolazile u hram svakoj je darivao po godinu u ciklusima od dvanaest godina. U Starom zavjetu se na više mjesta čita što se može, i kojom prilikom, prinijeti kao žrtva bogu Jahvi. Njemu se ne žrtvuje vola ili ovna „koji bi na sebi imao manu ili kakvo zlo" (Pnz, 17:1) dok se janjci, ovan i junac prinose za židovske blagdane (Br, 2829). Žrtva se prinosi od krupne ili sitne stoke (Lev, 1:2). Od krupne stoke „muško bez mane“ (Lev, 1:3) od sitne stoke - ovca ili koza - isto muško „bez mane“ (Lev, 1:10). U Post 15:9 Jahve traži da mu se za žrtvu prinese junica od tri godine. Tele se prinosi Jahvi za žrtvu okajnicu (Lev, 9:2). Jahvi se za žrtvu može prinijeti i koza (Lev, 3:12), muško jare bez mane (Lev, 3:23), a može i žensko jare bez mane (Lev, 3:28). Jednogodišnje janje bez mane prinosi se kao žrtva paljenica; jednogodišnje žensko janje bez mane kao žrtva okajnica $(\mathrm{Br}, 6: 14-15)$. Da se žensko janje, bez mane, prinosi kao žrtveni dar Jahvi ponavlja se i u Lev 3:32. Žrtvovanje janjeta u obrednim ritualima spada među najstariji način prinošenja žrtve te se nekad, kao žrtva, prinosio u vrijeme haranja kuge. Janje je žrtvena životinja u obredu za židovski blagdan Pashe dok je janjetina je tradicionalni obrok kršćanima za blagdan Uskrsa. Janje je simbol Krista te ga često nalazimo u kršćanskoj umjetnosti, a u Bosanskoj krajini, za Đurđevdan ${ }^{12}$, kolju janje koje nazivaju „đurđevilo“. Romi u Vranju (Srbija) za Erdelez (Đurđevdan) prinose kao krvnu žrtvu bijelo, uhranjeno janje, a djeca se po licu mažu janjećom krvlju, kako bi bila zdrava i crvena. Danas se za onog za koga se smatra da nije kriv kaže da je žrtveno janje te se pod time podrazumijeva i prebacivanje krivnje na drugoga. Danas životinjsku žrtvu prinose pripadnici islama (klanje kurbana), sljedbenici santerije (Karibi), te sljedbenici nekih plemenskih religija u Africi. „U Djelima apostolskim Pavao i Barnaba osuđuju žrtvovanje životinja kao posve beskorisno" (Eagleton, 2019:34). U mnogim religijskim

12 Blagdan u čast početka proljeća i svetog Đurđa. Slave ga, šestog svibnja, Srbi, Romi, Makedonci, Crnogorci, Albanci. To je blagdan stočara kao i blagdan rodnosti. Za Rome to je, po rangu, treći blagdan. Proslavljaju ga svi Romi bez obzira na konfesionalnu pripadnost. 
kulturama razvijeno je proricanje na osnovi dijelova tijela neke životinje. Može to biti proricanje iz utrobe žrtvovane životinje. Tako se u starorimskoj religiji božanska volja određivala na osnovu jetre žrtvovane životinje. Postojao je i svećenik koji je proricao na osnovu promatranja jetre, pluća i srca žrtvovanih životinja. Obrede je ukinuo car Konstantin, koji je priznao kršćanstvo kao religiju Rimskog carstva. Proricati se može i na osnovu kuhane glave neke životinje (tzv. kefolomantija). Na Balkanu je razvijen običaj proricanja iz janjeće plećke.

Mnoge religijske tradicije reguliraju uzimanje žrtvenog, ili mesa uopće, za hranu. Tako je u vrijeme totemizma, jednog od prvobitnih oblika religije, postojala praksa da se jednom ili dva puta godišnje ubijalo totema, zaštitnika, jelo se njegovo meso i pila njegova krv, zbog duhovne obnove. Ritualno klanje životinja postoji u židovstvu i islamu. Lev 11:2-8 određuje židovima koje kopnene životinje mogu jesti: „svaku koja ima papke, ali papke razdvojene, ne smijete jesti: devu [...] svisca [...] arnebeta [...] svinju“. Od vodenih životinja može se jesti: „sve što živi u vodi, a ima peraje i ljusku“ (Lev, 11:9). Od ptica zabranjene su: orao, jastreb, tetrijeb, sokol, gavran, noj, kobac, galeb, lastavice, sova, gnjurac, ušara, labud, pelikan, roda, čaplja, šišmiš (Lev, 11:13-19). Od životinja koje gmižu nečiste su: krtica, miš, gušter, kameleon, daždevnjak, zelembać i tinšamat (Lev, 11:29-30). Svaka zaklana stoka, mimo propisanog obreda, za pripadnike židovske religije, važila je kao „mrcina“. Osobe koje su klale životinje (šohet) morale su proći obuku kako bi stekle vještinu ritualnog klanja, a ritualno klanje se obavlja na najbezbolniji način i sastoji se u potpunom otjecanju krvi zaklane životinje, jer je zaostala krv pogodna za uzgoj najpatogenijih bakterija. Imajući u vidu da bakterije cirkuliraju krvnim sudovima, vjernik meso zaklane životinje i prije upotrebe stavlja u sol (do jedan sat) radi uništenja eventualnih zaostalih bakterija, nakon čega ga ispire u hladnoj vodi. Iz istih razloga židovi tumače i religijsku zabranu uzimanja beskičmenjaka za hranu te je iz jelovnika isključeno životinjsko meso prijemčivo za parazite. Rastafarijanci ${ }^{13}$ jedu ribe koje moraju biti dugačke tridesetak centimetara.

Zanimljivo je napomenuti u kojim se sve religijskim tradicijama izbjegavalo i izbjegava konzumiranje mesa. Tako znamo da su se bogumili suzdržavali od mesa, katari, pripadnici kršćanskog pokreta u Francuskoj, prakticirali su hranu bez mesa (vegetarijanci), pripadnici enkratita, gnostičke sljedbe na tlu Male Azije imali su zabranu konzumiranja mesa te su pripadnici zajednice Bratstvo križa i zvijezde, u Nigeriji, vegetarijanci. Također, i mnogi rastafarijanci su vegetarijanci, koji ako i jedu meso, odbacuju svinjetinu. Meso ne konzumiraju ni pripadnici kaodaizma, religijske zajednice osnovane u Vijetnamu 1919. godine dok u hinduizmu, samo svećenik jede žrtvovano meso. Budistička etika ne dopušta ne samo konzumiranje mesa, već i izgovaranje te riječi te tko upotrebljava meso za hranu snosi peterostruku odgovornost: za nabavku životinje, za klanje,

13 Religijski pokret nastao na Jamajci 1930. godine. Vjerovali su da će se 1960. godine u Africi okruniti crni car i pozvati crnce da se vrate u domovinu. Kada je etiopski princ (Ras) Tafari okrunjen pod imenom Haile Selasije Prvi, nazvali su se rastafarijanci. Poznati su po specifičnoj frizuri - „strašne kovrdže“ - duge pletenice koje liče na konjsku grivu. Vjeruju da je i Isus bio crnac. 
za strah i patnju koju ta životinja proživljava pri odvođenju na klanje, za naređenje podčinjenima da tu životinju ubiju, za bol koju ta životinja snosi dok je kolju i za nuđenje onoga što je gnusno Budi ili njegovu sljedbeniku. Sukladno tome, mesarski zanat smatraju nedopustivim (kao povreda ahimse, principa nenasilja). Budistički osmostruki plemeniti put, među ostalim, traži izbjegavanje zanimanja koja traže ubijanje (biti lovac, ribar, mesar). Džaini izbjegavaju meso i lov (zbog zabrane nasilja). Pripadnici pokreta Hare Krišna suzdržavaju se od mesa, ribe kao i pripadnici Hindu Vaišnavske zajednice izbjegavaju konzumiranje mesa. Prema Bhagavad-giti, nema potrebe da čovjek jede životinjsko meso (Bhagavad-gita, 1982:277). Meso izbjegavaju i pripadnici duhovne zajednice Komaja. ${ }^{14}$ Vidjeli smo da je pripadnicima židovske religije zabranjeno uzimati meso od divljači. Dopušteno je uzimanje mesa od životinja koje imaju razdvojene papke, preživača i domaćih životinja (janjetina, govedina, piletina) dok meso uginule životinje ili životinje koju je rastrgla zvijer, nije dopušteno konzumirati.

$\mathrm{U}$ nekim religijskim tradicijama u vrijeme posta zabranjeno je konzumirati meso. Tako je pravoslavnima od Čistog ponedjeljka, vrijeme Korizme, zabranjena sva hrana životinjskog podrijetla, a treće nedjelje prije Vaskrsa pojede se sve meso u kući i ne jede do Vaskrsa. Kod katolika, u dane Korizme, nije dopušteno uzimati meso, a petkom je poželjno izbjegavati meso.

Donosimo i kratak osvrt na to koje životinje i kakvi simboliku imaju u religijskim tradicijama: U antilopama, prema vjerovanju afričkog naroda Bušmana, se može javiti božanstvo dok se u hinduizmu javlja kao simbol boga Šive. Bik je najčešće simbol snage što je vidljivo u sljedećim primjerima: Apis je bio staroegipatsko božanstvo štovano kao sveti bik, u grčkoj mitologiji javlja se Minotaur, neman, čovjek-bik, Asirsko i akadsko božanstvo Lamasu, bilo je predstavljeno s tijelom bika, ljudskom glavom i orlovskim krilima te se u starogermanskim religijskim tradicijama božanstvima se, kao žrtva, prinosio bik ili konj. Uz pomoć krvi žrtvovane životinje vršili su proricanje, a da bi dobili snagu, stari su Germani pili volovsku krv pomiješanu s medom i vinom. Prema iranskoj mitologiji postojao je praiskonski bik Geush Urvan, čuvar stoke, u mitraizmu postojao je obred taurobolij tijekom kojeg bi se iznad rešetke, ispod koje je u udubljenju stajao vjernik, klao bik da bi krv padala po njemu i očistila ga od grijeha. Prema kršćanskoj mitologiji sv. Sebastijan oživio je mrtva bika, a među plemenskim religijama kod Židova bik je mogao biti totem.

Deva kao životinja je simbol umjetnosti, znak kraljevske časti i dostojanstva. Prema Evanđelju, Ivan Krstitelj „bijaše obučen u odijelo od devine dlake“ (Mk, 1:6). Mahmel je deva koja nosi darove u Meku, a u suri 22:27 piše o ljudima koji će na hodočašće dolaziti jašući „na svakoj mršavoj devi koje dolaze s dalekog puta“. U suri 22:36 također piše o klanju devama i govedima kao kurbanima. U suri 91:13 govori se o „Božjoj devi 'ne koljite je'“ ili: „O moj narode, ovo je Božja deva, znak vama, pa je pustite neka pase

14 Riječ je o društvu za razvoj ljubavi i svijesti koju je u Zagrebu, 1978. godine, osnovao Aba Aziz Makaja (Franjo Milićević), rođen u Mostaru. 
po Božjoj zemlji“ (11:64). A u suri 54:27 čitamo kako će Bog ljudima poslati „devu kao iskušenje“. U suri 7:39 spominje se deva („niti će oni u dženet dok deva ne prođe kroz iglene uši“). Deva se spominje i u 7:72 („Pustite je da jede po Božjoj zemlji. Nemojte je zlostavljati pa da vas stigne kazna!"). Dupin, u kršćanskoj umjetnosti najčešće prikazivana morska životinja koja simbolizira uskrsnuće i spasenje. Prikazuje se kao prenosilac duha umrlih u drugi svijet, simbol uskrsnuća, a ponekad i samog Isusa. Nekad se vjerovalo da se impotenciju može liječiti krvlju jarca. Ovu se životinju prinosi Jahvi kao žrtvu okajnicu (Lev, 9:15). Jahve traži da mu se, za žrtvu, prinese kozlić ili janje (Izlazak, 12:5), a u knjizi Postanka (15:9) Jahve traži da mu se za žrtvu prinese koza od tri godine. U Starom zavjetu čitamo i sljedeće: „Aron [...] neka prinese oba jarca i postavi ih pred Jahvu (Lev, 16:7) neka potom zakolje jarca za žrtvu okajnicu za grijeh naroda“ (Lev, 16:15). Važno je i da je u ranoj kršćanskoj umjetnosti jarac simbol prokletnika na Posljednjem sudu.

Jelen je smatran za pretke Kelta i Germana kao simbol rodnosti, a zbog obnavljanja rogova, on je kod mnogobrojnih naroda, od Kine do Europe, uziman za simbol neprekinutog stvaranja i obnavljanja. Akteon, po grčkoj mitologiji, mladi lovac kojeg je božica Artemida, za kaznu što ju je promatrao dok se kupala, pretvorila u jelena. Jež je veoma prisutan u mitologiji istočne Europe zbog svoje mudrosti (naročito kod Rumunja, Bugara) te u mnogim drugim kulturama simbolizira mudrost. Konji su također izuzetno važni što se vidi na primjeru jednoroga koji je mitska životinja u obliku konja i predstavlja simbol nevinosti. U keltskoj mitologiji postojala je i božica konja dok je Usinsh bio bizantski bog proljeća i zaštitnik konja. Nadalje, kentaur, u grčkoj mitologiji je biće pola konj - pola čovjek. Grčka mitologija također poznaje i krilatog letećeg konja Pegaza. Osim navedenoga, konji su služili i kao prijevozno sredstvo i kao sredstvo rata (poznata priča o trojanskom konju). Za Solomona se kaže da je imao 12.000 konja (1 Kr, 10:26), a u suri 8:61 spominje se konj kao sredstvo u ratnom pohodu (sprem'te konje). Kod Indijanaca, starih Rimljana, konj je postao i vjerskim simbolom, a konji su ubijani u obrednim ritualima (npr. bijeli Pastuh) te su Grci bogu Posejdonu žrtvovali konja. Kult rodnosti također je povezan s konjem. Talmud upozorava „nemoj stanovati u gradu u kojem konj ne rže" (Talmud, 1982:280). U nekoliko sura čitamo o konjima. Tako u suri 16:8 piše: „[Stvorio je] i konje, mazge i magarce da ih jašete i [da vam budu] ukras“, a kasnije se govori o „konjima koji [u trku] dašću“ (100:1) „i nogama izbijaju iskre [iz kamenja]“ (100:2), „trkom uzvitlaju prašinu“ (100:4). Kornjača je simbol svemira (Kina), erotske snage i rodnosti, simbol dugovječnosti i besmrtnosti. Nekad je postojalo vjerovanje da zemlja počiva na leđima kornjača. Prema hinduističkoj predaji, Višnu se deset puta otjelovio: najprije (tri puta) u liku životinje (riba, kornjača, vepar), to je spasilo svijet od propadanja; četvrti avatar bio je čovjek-lav; peti patuljak; šesti Rama-Rama sa sjekirom; sedmi Rama; osmi Krišna; deveti Buda, deseti (koji tek treba doći) Kalki. Zlatnu kornjaču (cijelo joj tijelo ima blistavo zlatnu boju) u Nepalu smatraju utjelovljenjem boga Višnua.

Koza je u nekim religijskim tradicijama prinošena kao žrtveni dar te je bila i simbol seksualnosti i rodnosti. U Babilonu bi je prinosili kao žrtvu za ozdravljenje bolesne osobe. 
Koza je igrala određenu ulogu u starogrčkim vjerovanjima (o Zeusu, Dionizu i Apolonu). U skandinavskoj mitologiji vjerovalo se u kozu Hajrudin koja pase na vrh drveta svijeta i mlijekom hrani bogove dok se u drevnoj Indiji vjerovalo se da mlijeko od crvene koze štiti od nesreća. Stari zavjet nas upoznaje da se od kozlića priprema ukusan obrok (Post, 27:9). A u knjizi Postanka (30:32) čitamo o šarenoj ili „naprugavoj kozi“. U Bosni i Hercegovini postoji vjerovanje da kozje mlijeko ima ljekovito djelovanje (osobito kod bolesti jetre). Govoreći o kravama, u germanskoj mitologiji postojala je sveta krava (audumla), a prema grčkoj mitologiji svećenica Io, u koju se zaljubio Zeus, pretvorena u kravu, pobjegla je u Egipat gdje je, obrativši se u ženu, rodila Zeusu sina. Dok je krava za Europljanina domaća životinja, za hinduista ona simbolizira nešto sveto. Hinduisti se koriste samo njezinim mlijekom dok je klanje krave za hinduista nezamislivo. Odnos hinduista prema kravi kao svetoj životinji nije samo zbog toga jer daje mlijeko i sir, već zato jer je Krišnin pratilac. Iako hinduisti smatraju krave svetim životinjama, u vrijeme žrtvenih svečanosti (siječanj) one moraju proći kroz tzv. čistilište - veliku obredno zapaljenu vatru. Onaj tko se ne pridržava zabrane klanja krave, ne smatra se hinduistom. Hinduisti inače izbjegavaju konzumiranje mesa, govedine posebno. Nadalje, za hinduiste, kravlja je balega pročišćivač i sve što je zaprljano pročišćuje se dodirom s kravljom balegom. Vajšije (kasta trgovaca i zemljoradnika) dužne su brinuti se o zaštiti krava (Bhagavad-gita, 1982:739). Pod utjecajem hinduizma i siki ${ }^{15}$ poštuju svetost krave, inače ostalo meso konzumiraju ako je životinja ritualno zaklana (jednim zamahom noža) dok se Jahvi za žrtvu može prinijeti „goveče - žensko ili muško“, bez mane (Lev, 3:1). Kravu se prinosi i kao žrtvu pričesnicu, za narod (Lev, 3:18), a žrtva okajnica kod židova podrazumijevala je da se zakolje junac, a njegovo meso i koža spale (Izlazak, 29:14). U knjizi Izlaska, Jahve zapovijeda židovu da ne poželi vola bližnjega svoga (20:17) dok se u knjizi Izlaska regulira odšteta ako goveče ubode i usmrti čovjeka kamenovanjem (21:28), a ako je i prije bolo treba ga kamenovati (21:29) te ako ubode dječaka ili djevojčicu; kamenovati ga. Tko ukrade goveče ima da vrati petoro goveda (21:37), a tko umlati goveče, neka ga nadoknadi (Talmud, 1982:178). U suri 12:43 spominje se „sedam debelih krava kako ih jede sedam mršavih“. U Kur'anu 2:67 Bog naređuje da se zakolje krava „ni stara ni mlada; srednje dobi“, žuta, a ne ona koja je podvrgnuta radu oranju niti koja ima bilo kakav znak na sebi.

O lavu se piše često, a prema grčkoj mitologiji, grif je životinja s lavljim tijelom, orlovskom glavom i krilima. Artemida je božica lava, ali i gospodarica životinja koja je prikazivana u pratnji jelena. Aker je bio bog-lav u staroegipatskim vjerovanjima, lovci iz plemena Masai (Tanzanija) pili su krv ubijenog lava, a u hinduizmu lav predstavlja

15 Hinduističko-islamska sljedba nastala na području današnjeg Pakistana i sjeverozapadne Indije (Pandžab). Riječ je o spoju hinduističkog učenja i islama (monoteizam). Pripadnici svom imenu dodaju riječ „sing“ što znači „lav“, a žene „kaur“, što znači „princeza“. Obavezni su nositi pet amblema: nešišanu kosu, češalj u kosi, željeznu narukvicu, kratke hlače i mač. Nose brade i turbane kao vidljive znake svoje religijsko-nacionalne pripadnosti. 
branitelja zakona i Budine mudrosti, ponekad Buda sjedi na lavljem tronu dok u hinduizmu „čovjek-lav“ četvrti je avatar boga Višnua. Nadalje, u taoizmu lavlja lopta simbol je povlačenja uma i praznine, a lava predstavljaju kao kralja životinja. On je simbol snage (Što ima jače od lava - Suci, 14:18) i hrabrosti. Statue lava postavljane su na ulaznim vratima, grobnicama s ciljem zaštite od zlih sila. Među plemenskim vjerovanjima Židova, lav je bio jedan od totema te je zanimljivo da je autor jednog od evanđelja, Marko, predstavljen kao lav. Vjerojatno je to povezano s početkom Evanđelja gdje se govori o "glasu jednoga koji viče u pustinji“ (Mk, 1:3). Lisicu nalazimo u basnama, ali i u religijama te u Starom zavjetu čitamo da lisica može poslužiti da se pomoću nje zapali protivniku žito, vinograd i masline (Suci, 15:5). „Lisice imaju jazbine“ (Mt, 8:20), kaže se u Novom zavjetu te Anton Hangi navodi da su bosanski muslimani vjerovali da ako trudnoj ženi pređe lisica ili zmija preko puta, dijete će biti sretno i dugo živjeti (Hangi, 1989).

Govoreći o mačkama, jaguar je najveća vrsta američke mačke te je u ikonografiji Maja i Azteka, nezaobilazan. Aztečko zemaljsko božanstvo Tepeyollotl, prikazano je u liku jaguara. U Kini se vjerovalo da se mrtva mačka može pretvoriti u demona, a u drevnom Rimu, mačka je bila simbol slobode. Neke božice, poput rimske Dijane, predstavljane su u liku mačke, a u starom Egiptu, u svetištu Bubastis, pronađeno je na tisuće mumificiranih mačaka. Postoji i mit o crnoj mački kao simbolu lošega. Naime, crna mačka često se spominje u crnoj magiji te se tako vjeruje da ako crna mačka pređe preko puta, djevojka će zastati, popravljati čarapu na nozi (iako je sa čarapom sve u redu), dok netko ne prođe te se vjeruje da će se nešto loše desiti ako crna mačka pređe preko puta. I za Japance mačka je zloslutna životinja. Budisti vjeruju da samo mačku i zmiju nije potresla Budina smrt, a u islamskoj tradiciji crna mačka nije dobroćudna. Inače, u mnogim predajama crna mačka simbolizira nesreće i smrt.

Govoreći o magarcu, on je simbol smjernosti, mira, strpljenja, gluposti, razvratnosti i rodnosti. U hinduizmu magarac je vukao Ravanina nebeska kola kad je oteo Situ dok je u kršćanstvu simbol Kristovog rođenja i bijega u Egipat. Isus je, jašući na magarcu, ušao u Jeruzalem (Mt, 21:4), a od svih pisanih religijskih autoriteta monoteističkih religija o magarcu najviše možemo čitati u Starom zavjetu i Talmudu. Tako u Sucima čitamo da magareća čeljust može poslužiti da se njom pobije tisuću Filistejaca (Suci, 15:16), u knjizi Postanka 12:16 čitamo kako je Abraham u Egiptu „stekao stoke i goveda“, „magaraca [...] magarica i deva“. Na magarcima se progonilo žito iz Egipta u zemlju Kanaan (Post, 42:26). Svaka prvina magaradi otkupljuje se janjetom ili jaretom (Izlazak, 13:13), a u plug se ne uprežu zajedno vol i magarac (Pnz, 25:10). Magarac i deve spominju se kao dio bogatstva (Post, 24:35) te zato u knjizi Izlazak, Jahve zapovijeda židovima da ne požele magarca bližnjega svoga (20:17). Mojsije se sa ženom i sinovima, na magarcu, vraća u Egipat (Izlazak, 4:20). Prema Talmudu, ždrijelo magarice stvoreno je u predvečerje subote, za sutona (Talmud, 1982:163). U Kur’anu (62:5) piše o „magarcu koji nosi knjige (a ne zna što je u njima)“.

Majmun ima različitu ulogu u religijskim kulturama od magarca. Od štovanja božanstva u liku majmuna do religijski legendi, štovanje majmuna nalazimo u starom Egiptu o 
čemu svjedoči njihovo prisustvo u egipatskoj umjetnosti. Majmunska božanstva nalazimo također i u azijskim religijskim kulturama. Hinduistima je zabranjeno ubijanje majmuna jer poštuju Hanumana boga-majmuna koji simbolizira snagu, te za blagdan Divali, blagdan svjetlosti u čast božice Kali i Lakšmi, slave svjetlo i pobjedu boga Rame nad desetoglavim demonom Ravanom uz pomoć majmunskog boga Hanumana i majmuna. Kur’an napomine, u suri 7:165, da se o onima koji su se ogriješili kaže „budite prezreni majmuni“. U zapadnoeuropskoj tradiciji, za nestašne osobe, postoji uzrečica „majmune jedan“. Nadalje, o medvjedu nalazimo vjerovanja mnogih naroda u Aziji, Europi, Sjevernoj i Južnoj Americi. Kod nekih plemena u Americi postojalo je vjerovanje da se nakon smrti mogu ponovno roditi kao Veliki Medvjed. Germanski ratnici, berserki, odijevali su se u medvjeđa krzna, vjerujući da su tada neranjivi, a stari su Norvežani, tijekom lova, pili krv medvjeda. Leib-olmai laponski je bog medvjeda, a sljedbenici domorodačke religije ainu u Japanu štovali su medvjeda kao vrhovno božansko biće. Azijski crni medvjed igra određenu ulogu u tradicionalnoj medicini (Kina) za čije se meso vjerovalo da daje ljudima snagu. U istočnoj se Hercegovini vjerovalo da konzumiranje medvjeđeg mesa jača muškost dok se u Bosni vjeruje da salo medvjeda pomaže u liječenju reumatičnih bolesti.

Ovan često predstavlja simbol snage dok u religijskim tradicijama poseban je naglasak stavljan na ovna, povezujući ga s muškosti. Bog vatre Agni, u Indiji, prikazivan je u obliku ovna, a pokrov šatora pravi se od „u crveno obojenih ovnujskih koža“ (Izlazak, 26:14). Prinosi ga se za žrtvu pričesnicu ( $\mathrm{Br}, 6: 14)$ te se Jahvi prinose darovi od ovnujske kože (Izlazak, 25:5). Ovan se također prinosi kao žrtva paljenica (meso ovna spaljuje se na žrtveniku) (Izlazak, 29:18). U knjizi Postanka 15:9 čitamo kako Jahve traži da mu se za žrtvu prinese ovna od tri godine, a u istoj knjizi (Post, 22:13) čitamo kako je Jahve Abrahamu ponudio ovna za žrtvu paljenicu umjesto njegovog sina Izaka. Govoreći o ovci, ona se, kroz povijest religija, pojavljuje kao žrtveni dar, sve do danas. U nekim religijskim tradicijama važila je za totemsku životinju te je bila totemska životinja u nekim plemenskim religijama Afrike (npr. Batoro, Bušmani). Prikazana je u umjetnosti Mezopotamije, Afganistana, Irana, a u religijskoj tradiciji Yoruba, ovca je zamjenska žrtva - prinose nju, umjesto čovjeka, kao žrtveni dar. Postat će žrtvena životinja i u židovskoj religiji, drevnoj Kini te islamu. U knjizi Postanka (30:32) čitamo o „garavoj ovci“, a da one također idu za pastirom jer poznaju njegov glas čitamo u Novom zavjetu (Iv, 10:4). "Ovca je ponekad jednako dobra kao i čovjek kada treba pridobiti božansku naklonost“ (Eagleton, 2019:19). Krista se u evanđeljima naziva „Jaganjcem Božjim“, Agnus dei, Janje Božje, simbol je za Krista u slikama s religijskim motivima, kako je Ivan Krstitelj nazvao Isusa. Agnus paschalis, „uskrsno janje“, nekad je bio obavezni dar biskupu od župnika. Muslimani za Kurban-bajram prinose žrtvu - kurban, a to može biti goveče, jare, ali je na Balkanu uobičajeno da to bude ovan. Kurban, prije klanja, okrenu prema kibli, lijeve mu noge zavežu za prednju desnu, a meso od kurbana ne prodaju niti upotrebljavaju za prismok.

Govoreći o psu, on je predstavljen kao simbol budnosti i vjernosti. „Običaj jedenja pasa, koje se [među slovačkim Romima] smjelo obavljati samo u okviru posebnih obreda i 
svečanosti, bio je tajna koju su svi znali i o njoj nitko nije govorio" (Graus, 2018:85). Pseće se meso također konzumira u Kini i Koreji. Talmud upozorava: „nemoj stanovati u gradu u kojem pas ne laje“ (Talmud, 1982:280). U suri 7:175 govori se o psu koji plazi jezik kad ga potjeraš i kad ga ostaviš. Ljudi koji vole pse daju im različita imena te tako književnica Barbara Kingsolver u romanu Bez zaklona piše o psima: „Haribda je pripadao hodočasničkoj crkvi, dok je Scila bio baptista. (Voleo je vodu)“ (Kingslover, 2019:81).

Riba često simbolizira uzajamnost života i smrti. Grčka božica Afrodita štovana je i kao božica ribe, a maorski bog riba i mora zvao se Tangarda. U plemenskim religijama, riba je simbol snage klana, a na području Mediterana i Bliskog istoka ljudi su ih povezivali s velikim božicama ljubavi i mudrosti. Mnogi bogovi i božice obožavani su u obliku ribe dok je u Babilonu riba bila sveta hrana svećenika. Hinduisti nikad bogu Krišni ne nude meso, ribu ili jaje, već list, cvijet, voće ili vodu te nikad neće zajedno konzumirati ribu i mlijeko. Po naučavanju New Agea, svijet je prošao kroz period utjecaja Bika (mezopotamske religije), Ovna (židovska religija), a doba kršćanstva nastalo je pod astrološkim znakom Ribe. To kršćansko doba, pod znakom Ribe, isteklo je oko 2000. godine i na pomolu je nat konfesionalno novo doba (pod znakom Vodenjaka). Pripadnicima židovske religije od riba, dopušteno je jesti one koje imaju peraje i krljušti te za Novu godinu židovi jedu ribu da bi bili plodni poput ribe i kretali se naprijed. Židovi je jedu i subotom, na Sabat, a posuđe za subotu često je ukrašeno motivima ribe. Za blagdan Roš Hašana (Nova godina) pripadnici židovske religije za večeru serviraju ribu s glavom „da bi bili glava, a ne rep među narodima“. Simbolički se želi iskazati želja da židova bude onoliko koliko ima riba u moru. Sto pedeset i tri ribe su se ulovile u mrežu kad se Isus apostolima ukazao kod Tiberijskog jezera, izvješćuje Ivan u Evanđelju (Iv, 21:11). U ranom kršćanstvu riba je simbolizirala Krista, ona je simbol i ranokršćanske umjetnosti. Isus je „ribar duša“, među apostolima su ribari, a Isus na čudesan način ribom hrani mnoštvo. Isus je $s$ dvije ribe nahranio mnoštvo (Mt, 14:19-20), odnosno, $s$ „malo ribe“ nahranio je „četiri tisuće muškaraca, osim žena i djece“ (Mt, 15:34-38), a prema Markovom evanđelju čak pet tisuća muškaraca (Mk, 6:44). Mitra je riboglava kapa koju su nosili židovski prvosvećenici, kao i biskupi tijekom obreda te je simbol je papinske, nadbiskupske i biskupske vlasti. Naime, papa, kardinali, biskupi za vrijeme obreda nose mitru u obliku riblje glave. Katolici petkom, u vrijeme posta, jedu ribu, dok pravoslavni vjernici, u vrijeme posta, ne konzumiraju ribu jer pravoslavci u vrijeme posta i izbjegavaju masnu hranu. Opat Ranse (1664) zabranio je trapistima ${ }^{16}$ jesti ribu. Osim toga što riba služi za jelo „njeno srce, jetra i žuč koristan su lijek“ (Tob, 6:4), ali ne kaže se za što. Pripadnici religije umbanda (Brazil) razvili su također i praksu proricanja na osnovu unutrašnjosti ribe (hitomantija).

16 Trapisti, red osnovan u Francuskoj u gradu La Trape. Jedan je od najstarijih i najsamozatajnijih redova u Katoličkoj crkvi. Imaju samostan Marija Zvojezda u Dolibašinom Selu kod Banjaluke, osnovan 1869. Nekad je to bila najveća trapistička opatija na svijetu, a prva među slavenskim narodima. Čuveni sir trapist dobio je ime po ovome redu. 
U hinduizmu slon simbolizira boga Ganeša, a u hinduističkoj mitologiji, zemlja počiva na leđima slonova te su oni simbol kraljevske snage. Prema budističkoj mitologiji Buda je začet kada je njegova majka sanjala njegov silazak s neba u obliku bijelog slona. Od abrahamskih religija (židovstvo, kršćanstvo, islam) samo se u Kur’anu, u suri 105:1, spominju slonovi. Govoreći o svinjama, one se „ubrajaju među najinteligentnije i najljubopitljivije sisavce, nad kojima prednjače možda jedino veliki majmuni“ (Harari, 2019:442). U hinduističkoj tradiciji, svinja se javlja kao avatar boga Višnua. Svinja ima važnu ulogu u mitovima i ritualima u jugoistočnoj Aziji te je njena glava simbol budističke božice Vajravarahi (Tibet, Nepal). U donjem desnom uglu hilandarske ikone „Povratak bludnog sina Ocu“ naslikano je pet velikih i dva mala prasca. „U mnogim društvima na Novoj Gvineji nečije bogatstvo se po tradiciji procenjuje prema tome koliko svinja dotični poseduje. Da im svinje ne bi bežale, njihovi vlasnici svakoj odseku deo njuške, što izaziva užasan bol kad god životinja pokuša nešto da onjuši. Pošto svinje bez njuškanja ne mogu da pronađu hranu, pa čak ni da se orijentišu pri kretanju, ovim sakaćenjem postiže se njihova potpuna zavisnost od ljudi koji ih poseduju. U nekim drugim delovima Nove Gvineje običaj je da se svinjama izvade oči tako da ne mogu čak ni da vide kuda idu" (Harari, 2019:132). Svinja u nekim religijama predstavlja nešto nečisto i zabranjeno (kod židova, muslimana), a kod drugih nešto sveto. Mišna zabranjuje židovima uzgoj svinja bilo gdje, a sitnu stoku „u zemlji Izraela“, osim u šumama dok je u židovskoj religiji zabranjena prehrana svinjskim mesom i upotreba svinjske masti. Zabranu konzumiranja svinjskog mesa nalazimo i kod Asiraca, Egipćana, Babilonaca te svinjsko meso nisu jeli ni sljedbenici boga Atisa, narod Pesinusa te obožavatelji Adonisa. Kur'an (2:173) zabranjuje konzumiranje svinjetine i prehrambenih proizvoda koji u sebi sadrže tu komponentu te adventisti sedmog dana ne konzumiraju svinjsko meso. Inače, hrana im mora biti bez začina i masnoća životinjskog podrijetla, a svinjsko meso ne konzumiraju ni pripadnici/ce rastafarijanskog pokreta (Karibi, Engleska, SAD). Isus šalje „nečiste duhove“" u svinje i one se podave u moru (Mk, 5:12-13). Međutim, kršćanima na Balkanu namenica naziv je za svinju namijenjenu za božićnu pečenku.

Dok su židovi bili u pustinji obožavali su tele (tzv. mosholatrija). „Zlatno tele“ simbol je idolatrije, pohlepe za novcem te se i u Kur'anu spominje tele kojem se narod klanja (2:54; 2:92-93; 4:153). U suri 7:181 kritizira se obožavanje „zlatnog teleta“, kao i u suri 20:88-91 gdje se piše o obožavanju teleta. Ibrahim časti poslanike "pečenim teletom“ (11:69), a u suri 51:26 piše o „debelom pečenom teletu“. Nastavljajući dalje o životinjama, vuk je simbol odmetnika i bjegunca. U nekim religijskim tradicijama (poput kineskih) simbol je pohlepe. Mnogi stari ratni bogovi nosili su naziv vuk, a lik vuka i danas stoji u svetištu u Delfima. Rimljani su vuka povezivali s bogom Marsom dok je u Bibliji je predstavljen kao „grabežljivo“ biće, u suri 12:13-17 spominje se vuk koji može pojesti čovjeka. U narodnim vjerovanjima postoje legende o vukodlacima kao osobama koje mijenjaju oblik u vuka. Mit o vukodlacima raširen je u Europi, ali i drugdje te je motiv i u književnosti. U plemenskim religijama Sjeverne Amerike, u središtu stvaranja stoji zec. U Mezopotamiji i Siriji zec je bio simbol smrti i ponovnog rađanja, a u ranom kršćanstvu, lik zeca stavljan je na nadgrobne ploče. Danas među kršćanima jaja uskrš- 
njeg zečića simboliziraju izvor života. Hangi navodi vjerovanje Bošnjaka po kojem ako zec pređe ispred trudne žene, dijete će biti nesretno, sebično i propalica (Hangi, 1989). U Europi simbol rodnosti, na Srednjem istoku, u Indiji, Kini također predstavlja zmija. U hinduizmu zmija je izuzetno cijenjena životinja te u hinduističkoj legendi, postoji džinovska zmija na kojoj je ležao bog Višnu. Iz Bhagavad-gite vidimo da zmije mogu biti i božanske (1982:493). Nag Panchami je naziv za hinduistički festival posvećen zmijskoj božici, a održava se u blizini Kalkute. Zmija je izuzetno cijenjena životinja u hinduizmu, Klu je zmijsko božanstvo u tibetanskom budizmu, a Manaša je božica zmija u Bengalu. Među plemenskim vjerovanjima Židova, zmija je bila i totem te se u različitim pisanim religijskim izvorima opisuje se pretvaranje štapa u zmiju. Tako su oko krilatog štapa (tzv. kaducij) boga Merkura ovijene dvije zmije. Također i u knjizi Izlaska, Mojsijev se štap pretvara u zmiju (Izlazak, 4:3), ali i Aronov (Izlazak, 7:9-10). Musin štap postade „prava zmijurina“ (7:106), a u suri 20:19-20 govori se kako Bog naređuje Musi da baci štap „i on postade zmija koja gmiže“. U suri 27:10 Musa baca svoj štap koji se kreće kao brza zmija. Ista se priča ponavlja i u suri 28:31 te u suri 26:32 pripovijeda se kako je Musa „bacio svoj štap, a on [postade] prava zmija!“ Nadalje, u knjizi Postanka (49:17) čitamo o zmiji „guji pokraj staze“, a gdje također piše i da je zmija bila lukavija od „sve zvjeradi što je stvori Jahve, Bog“ (3:1). Ona je navela Evu i Adama da uberu i pojedu plod s drva spoznaje, a na to Bog reče zmiji (3:14) „Kad si to učinila, prokleta bila među svim životinjama i svom zvjeradi divljom! Po trbuhu svome puzat ćeš i zemlju jesti sveg života svog“ (3:15). „Neprijateljstvo ja zamećem između tebe i žene, između roda tvojeg i roda njezina; on će ti glavu satirati, a ti ćeš mu vrebati petu. "17 Unatoč svemu, Sv. Franjo zmiju oslovljava sa sestro. Novi zavjet upozorava kako su zmije mudre (Mt, 10:16). Nadalje, Zebanija je, prema islamskom vjerovanju, zmija koja muči ljude u paklu. Na jugoistoku SAD-a članovi nekih karizmatskih crkava vrše bogosluženje držeći u rukama žive zmije otrovnice, a pomoću zmija može se proricati nečija sudbina (tzv. ofiomantija). Sljedbenici zen-budizma u Japanu često na svojim crtežima imaju žabu. Simbolički, kao što žaba satima može stajati na jednom mjestu, i osoba koja meditira isto tako satima miruje. Žaba od žada čuva se u Istočnoj Aziji kao kućna relikvija, a u narodu postoji vjerovanje da kreketanje žaba najavljuje kišu.

I ptice igraju određenu ulogu u religijskim tradicijama. Čak se dokazivalo postojanje Boga (tzv. ornitoteologija) na osnovu postojanja ptica i njihovog života. One su simbol ukazanja duhova, glasnogovornice božanskih bića. Ptica može biti i totem, mitski predak. Nemglan je irski bog ptica, u vjerovanjima naroda Keta iz Sibira, Tomam je božica ptica selica. Starorimski svećenički zbor (auguri) proricao je volju bogova po letu i glasu ptica. U Starom zavjetu čitamo da je Bog stvorio ptice (Post, 1:20), a u Post 2:19 kaže

17 „Priča o Adamu i Evi koji jedu sa stabla spoznaje mitski je zamišljaj o dvojakom utjecaju znanja na ljudsku slobodu. Umjesto da oslobađa, znanje se može upotrijebiti u svrhu porobljavanja. O tome je riječ kad se, pojevši zabranjenu jabuku nakon što im je guja obećala da će postati poput bogova, Adam i Eva nađu izgnani iz rajskog vrta i osuđeni na život neprestanog rada." (Gray, 2020:21) 
se da je Bog od zemlje stvorio „sve ptice u zraku“. Nadalje, u knjizi Postanka (6:7) čitamo da se Jahve pokajao jer je napravio „zvijeri, puzavce i ptice u zraku“. Zašto onda u Post 6:20 Jahve Noi zapovijeda da, u vrijeme potopa, u korablju stavi: „Od ptica prema njihovim vrstama, od životinja prema njihovim vrstama i od svih stvorova što po tlu puze prema njihovim vrstama: i po dvoje od svega neka uđe k tebi da preživi“? U knjizi Postanka (7:3) Jahve naređuje Noi da uzme „od ptica nebeskih po sedam parova - mužjaka i ženku - da im se sjeme sačuva na zemlji“. Tamo čitamo i kako ptice jedu meso obješena čovjeka (40:19), a u Novom zavjetu čitamo: „Pogledajte ptice nebeske! Ne siju, ne žanju niti sabiru u žitnice, pa ih ipak hrani vaš nebeski Otac“ (Mt, 6:26). „Ptice nebeske“ imaju gnijezda (Mt, 8:20) dok se u Kur’anu (105:3) spominju „jata ptica“. U suri 12:41 spominju se ptice koje jedu ljudsku glavu. U nekim primorskim krajevima zlogodnica je ptica za koju vjeruju da donosi loše vrijeme ili kakvu nesreću.

Simbolika ptica u pojedinim religijskim tradicijama se prikazuje na sljedeće načine: za feniksa, pticu sličnu orlu, u egipatskoj se mitologiji vjerovalo da je utjelovljenje boga Ra. Ptica iz egipatske mitologije, smatrana dušom boga Ozirisa, a riječ je o ptici prelijepe boje, čiji životni vijek traje do 500 godina. Povremeno bi bio spaljen na žrtvenoj lomači, ali bi opet čudesno uskrsnuo još jači. U ranom kršćanstvu, čest je simbol na nadgrobnim spomenicima, kao simbol uskrsnuća mrtvih. Golub je simbol nevine duše, duhovne čistoće, a u židovskoj religiji, golubica se prinosi kao žrtva u obredu očišćenja, nakon rođenja djeteta. Kad se Isus rodio, i njegovi roditelji su za žrtvu prinijeli dvije grlice i dva golubića (Lk, 2:24). Golubovi su „bezazleni“, stoji u Matejevom evanđelju (Mt, 10:16) te je golubica u ranoj kršćanskoj umjetnosti simbol čistoće i mira. Čest motiv je bila golubica koja nosi maslinovu grančicu. Bijela golubica je i simbol Duha Svetoga te danas mnogi, od mlade i mladoženje do političara i pape, puštaju bijelu golubicu kao simbol mira i dobrote. Goluba nalazimo ucrtanog na nadgrobnim spomenicima gdje simbolizira dušu umrloga. Grlica na Bliskom istoku simbolizira božicu plodnosti te u knjizi Postanka (15:9) Jahve traži da mu se za žrtvu prinese jedna grlica. Guska je simbol budnosti i pravednosti, a u plemenskim religijama zapadne Afrike, u žrtvenim obredima, prinošene su kokoši ili patke. Uobičajeno je i proricanje po kokošima (tzv. pulomantija). Labud je simbol duha i slobode te u mnogim religijskim tradicijama označava dušu. Brahma je prikazan nošen na labudu, božanskoj ptici, a u Starom zavjetu ga ubrajaju među nečiste ptice. U kršćanskoj tradiciji simbolizira čistoću, simbol Djevice te fraza „labudov pjev“ dolazi iz legendi da labud prije smrti ispušta glas koji podsjeća na tužnu pjesmu. Uobičajeno se pod tom frazom misli na posljednje djelo, koje autor smatra važnim i kojim se završava njegov autorski ciklus. Orao je u mnogim starim religijama povezan sa smrću - on odnosi duše umrlih u nebo. Orlovi i jastrebovi glasnici su bogova te je bog Horus, u staroegipatskim religijama, prikazan kao jastreb s glavom muškarca, a aztečki bog sunca i rata, Huitzilopochtli, simbolizira orla. Orlovi su tamo „gdje bude trupla“ (Lk, 17:37). Orao je također simbol uskrsnuća u kršćanskoj simbolici te se nalazi u grbu mnogih naroda, često povezan $s$ kraljevskom moći. Tako se dvoglavi orao javlja u grbu Nemanjića, Lazarevića i drugih plemićkih obitelji. Danas je on „utkan“ u grb Albanije, Rusije, Srbije i Crne Gore. Paunovi su „rajske ptice“ i u 
kršćanskoj umjetnosti simbol besmrtnosti čije je pero simbol sv. Barbare ${ }^{18}$. Pelikan se smatra svetom pticom za muslimane i masone, dok je pijetao simbol šintoističke božice Amaterasu (Japan). Nekad se proricalo na osnovu pijetlovog kljucanja u okviru kruga podijeljenog na 24 dijela (tzv. alektromantija). U pisanom izvoru kršćanstva pijetao je poznat po tome što će na njegov pjev Petar zanijekati poznanstvo sa Isusom. U pustinji Sinaj, kad je Mojsije izveo židove iz Egipta, pojaviše se prepelice i prekriju tabor (Izlazak, 16:13), dok u Kur'anu (2:57) se kaže da je Bog poslao prepelice, da ih se jede. Prepelica je simbol Crkve i istine, ali i prijevare i krađe: „Prepelica što leži na jajima, a ne leže jest onaj što nepravdom stječe bogatstvo" (Jer, 17:11). Roda je simbol budnosti, pobožnosti i čistoće, a kršćani je povezuju s Navještenjem. Roda najavljuje dolazak proljeća, a navješćuje i Kristov dolazak. Sova predstavlja duhove, anđele, ali i zbog njihove noćne prirode, i znak smrti i tame te je simbol boga tame te se u nekim poganskim religijama vjerovalo se da sove utjelovljuju duše umrlih. U staroj Grčkoj bile su simbol mudrosti, a u židovskoj religiji, sova simbolizira sljepilo, spada među nečiste ptice koja može biti i simbol Sotone i samoće. Ševa je simbol poniznosti i svećeništva, tuka koju katolici jedu na Badnji dan naziva se badnjara. Konačno, irska božica Bodb, prikazivana je u liku vrane, a u suri 5:34 spominje se vrana koja „kopa po zemlji“.

\section{ZAKLJUČAK}

Pokazalo se da su još prvobitna vjerovanja bila povezana s kultom prirode i obožavanjem raznih elemenata u njoj (totemske životinje i drveće, obožavanje planina, svetih mjesta u prirodi, svetih rijeka, obožavanje Sunca, Mjeseca...). Možemo zaključiti da drveće, cvijeće, životinje i ptice imaju svoju ulogu u religijama i religijskim tradicijama. Osobito njihova uloga dolazi do izražaja u religijskim obredima (obredima životnog ciklusa, žrtvenim obredima, kalendarskim...), najčešće kao obredno sredstvo. U nekim religijama cvijeće je puno simbolike i služi u obredima, osobito pri obredima rođenja, sklapanja braka i smrti.

Životinje su, kroz povijest, imale svoje mjesto u religijskim vjerovanjima, praksi, obredima, religijskoj umjetnosti, književnosti, plesu inspiriranom religijom, i sl. Tako se i desilo da su religijske tradicije imale utjecaja na čovjekov odnos prema raznim životinjama, sve do njihovog obožavanja. Religijske tradicije svoj stav o pojedinim životinjama prenose s generacije na generaciju: bilo da se radi o prinošenju neke životinje u obredima, bilo da se radi o zabrani konzumiranja njezinog mesa i sl.

$\mathrm{Na}$ kraju, sociologija religije i religiologija trebaju se, više nego do sada, baviti pitanjima odnosa religija - priroda pa i ulogom drveća, cvijeća, životinja i ptica u religijama i sličnim temama. Današnje generacije imaju posebnu odgovornost - u odnosu na buduće generacije - za planet Zemlju. Ne propagirati čovjekovu prevlast u prirodi i kozmosu, nego kultivirati njegovo zajedništvo s prirodom i kozmosom, kaže se u Deklaraciji o svjetskoj etici (Küng i Kuschel, 1993), koju su prihvatili predstavnici svih „velikih“ svjetskih religija.

18 Kršćanska svetica koje se dan proslavlja četvrtog, odnosno sedamnaestog prosinca. 


\section{LITERATURA}

Badurina, A. (ur.) (1979). Leksikon ikonografje, liturgike i simbolike zapadnog kršćanstva. Zagreb: Sveučilišna naklada Liber, Kršćanska sadašnjost i Institut za povijest umjetnosti.

Bhagavad-gita (1982). New Delhi: Heritage Publications.

Eagleton, T. (2019). Radikalno žrtvovanje. Zagreb: Ljevak.

Graus, K. (2018). Europa - neotkriveni kontinent. Zagreb: Fraktura.

Gray, J. (2020). Sedam tipova ateizma. Zagreb. TIMpress.

Green, J. (2020). Čudnovato drveće. Zagreb: Planetopija.

Hangi, A. (1989). Život i običaji muslimana u Bosni. Sarajevo: Svjetlost.

Harari, J. (2019). Sapijens: kratka historija čovečanstva. Beograd: Laguna.

Kingslover, B. (2019). Bez zaklona. Beograd: Laguna.

Küng, H. i Kuschel, K. J. (1993). Global Ethic: The Declaration of the Parliament of the World's Religions. London: SCM Press

Kur’an (prijevod Čaušević, Dž. i Pandža, M.) (1968). Zagreb: Stvarnost.

Saramago, J. (2017). Kameni splav. Beograd: Laguna.

Stern, H. (1993). Čovjek iz Apulije. Zagreb: August Cesarec.

Talmud (prijevod Werber, E.) (1982). Rijeka: Otokar Keršovani.

Žižek, S. (2019). Kao lopov usred bela dana. Beograd: Laguna. 


\title{
TREES AND ANIMALS IN WORLD RELIGIONS
}

\section{Ivan Cvitković}

\begin{abstract}
This paper aims to encourage research on the role of trees, flowers, animals, and birds in religions in religions and religious traditions. We use the method of content analysis, primarily relying on the "scriptures" (Bhagavad-gita, the Bible, the Qur'an, and the Talmud). In the introduction, we point to how nature has been included in religions long before the emergence of modern environmental movements. This has recently led to the development of a separate theological discipline as well-ecological theology. Even the sociology of religion could not avoid the topic of the relationship between religion and nature. The first part of the paper deals with the topic that can rarely be found in the sociology of religion or religiology - the importance of trees and flowers in human religious life (tree as a totem, the role of mountains in religious traditions, trees in religious rituals...). We also discuss individual mentions of trees in mythologies and religious traditions (almond, acacia, oak, apple, linden, vine, olive, palm, pomegranate, fig...). We then look at the role of flowers in religions and religious traditions, especially ritual practices. We have selected those flowers that are most often mentioned and analyzed (cyclamen, iris, lotus, lily, rose). In the second part of the paper, we explore the role of animals and birds. We were particularly interested in the role of animals in sacrificial rites within different religious traditions; the tradition of divination based on a body part of an animal; avoiding meat consumption due to religious tradition, etc. We also give a brief overview of the symbolism of individual animals in religious traditions (bull, camel, goat, deer, horse, turtle, goat, cow, lion, fox, cat, donkey, sheep...). Birds also play a role in religious traditions (phoenix, dove, dove, swan, eagle, rooster, stork, owl...). We conclude that trees, flowers, birds, and animals have an important role in world religions and religious traditions, particularly religious rites such as ritual practices.
\end{abstract}

Keywords: religion, ecology, sociology, trees, flowers, animals, birds

\section{BÄUME UND TIERE IN RELIGIONEN}

\section{Ivan Cvitković}

\section{Zusammenfassung}

Durch diese Arbeit wollen wir der Forschung der Rolle von Bäumen und Blumen in Religionen und Religionstraditionen, sowie der Rolle von Tieren und Vögeln in den Religionstraditionen einen Impuls geben. Bei der Vorbereitung auf die Arbeit haben wir Inhalte analysiert, vor allem die Inhalte der ,heiligen Schrifte" (Bhagavad-gita, Bibel, Kur'an und Talmud). In der Einleitung weisen wir darauf hin, dass man sich mit der Natur der Religionen lange vor dem Entstehen der ökologischen Bewegungen beschäftigt hat. Neuerdings hat dies zum Entstehen einer gesonderten theologischen Disziplin gebracht, nämlich der ökologischen Theologie. Auch die Religionssoziologie konnte das Thema des Verhältnisses Religion - Natur nicht umgehen. Der erste Teil der Arbeit behandelt ein Thema, das man selten in der Religionssoziologie oder der Religiologie findet, nämlich Bäume und Blumen in Religionen und Religionstraditionen. In der Geschichte der Religionstraditionen (von „alten“ Religionen wie Hinduismus, Schintoismus, Budhismus, Taoismus bis Judentum, Christentum und Islam) haben wir versucht, auf die Bedeutung von Bäumen und Blumen im religiösen Leben des Menschen (Baum als Totem, Rolle der Gebirge in Religionstraditionen, Baum in Handlungen des Glaubens...) hinzuweisen. Wir haben auch Bäume berücksichtigt, die man am öftesten in Mythologien und Religionstraditionen erwähnt (Mandelbaum, Akazie, Eiche, Apfelbaum, Linde, Weinrebe, Olivenbaum, Palme, Granatapfelbaum, Feigenbaum...). Welche Rolle spielen Blumen in Religioinen und Religionstraditionen (besonders in Handlungen des Glaubens)? Wir haben uns besonders auf die Blumen konzentriert, die von den Autoritäten für Religionen am öftesten erwähnt und 
schriftlich analysiert werden (Zyklame, Iris, Lotos, Lilie, Rose). Gleich interessant war es für uns, die Rolle von Tieren und Vögeln in Religioinen und Religionstraditionen zu erforschen. Noch einmal haben wir analysiert, wie man ihre Rolle aus Perspektiven verschiedener Religionen sieht - vom Hinduismus bis zum Judentum, Christentum und Islam. Besonders interessant fanden wir die Tiere als Opfergaben in verschiedenen Religionstraditionen; die Tradition der Wahrsagung anhand des Körperteils eines Tieres; Vermeiden von Fleischkonsum aus Gründen der Religionstraditionen, usw. Wir haben auch kurz auf die Symbolik mancher Tiere in den Religionstraditionen hingewiesen (Bulle, Kamel, Ziegenbock, Hirsch, Pferd, Schildkröte, Ziege, Kuh, Löwe, Fuchs, Katze, Esel, Schaf...). Auch Vögel spielen in den Religionstraditionen eine bestimmte Rolle. Uns hat interessiert, welche Symbolik die Vögel in einzelnen Religionstraditionen (Phönix, Taube, Turteltaube, Schwan, Adler, Hahn, Storch, Eule...) haben. Der Schluß ist, dass Bäume, Blumen, Tiere und Vögel ihre Rolle in Religionen und Religionstraditionen spielen. Besonders kommt ihre Rolle zum Ausdruck in den Handlungen des Glaubens, meistens als Opfertier.

Schlüsselwörter: Religion, Ökologie, Soziologie, Bäume, Blumen, Tiere, Vögel 